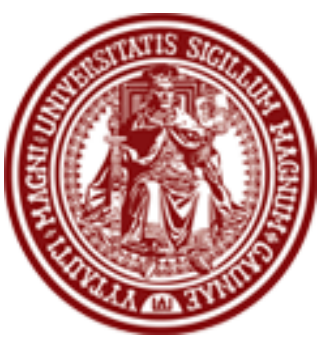

sciendo

\section{BALTIC JOURNAL OF LAW \& POLITICS}

A Journal of Vytautas Magnus University

VOLUME 12, NUMBER 1 (2019)

ISSN 2029-0454

Cit.: Baltic Journal of Law \& Politics 12:1 (2019): 62-86

https://content.sciendo.com/view/journals/bjlp/bjlp-

overview.xml

DOI: $10.2478 /$ bjlp-2019-0003

\title{
NON-GOVERNMENTAL CHILDCARE CENTRES IN A NEOLIBERAL ENVIRONMENT: THE CASE OF LITHUANIA
}

\author{
Ilona Tamutienè \\ Professor, Dr., Researcher \\ Vytautas Magnus University, Faculty of Political Science and Diplomacy \\ (Lithuania) \\ Contact information \\ Address: V. Putvinskio str. 23, LT-44243 Kaunas, Lithuania \\ Phone: +370 37206709 \\ E-mail address: Ilona.tamutiene@vdu.It
}

Received: April 9, 2019; reviews: 2; accepted: June 12, 2019.

\section{ABSTRACT}

The article examines how nongovernmental organizations (NGOs) working with children from poor and socially excluded families operate in the neoliberal environment. The case of non-governmental school-age childcare centres (SACCS) in Lithuania was analysed. SACCs provide social services to children from poor and socially excluded families. The study is based on 62 qualitative interviews with experts working in non-governmental SACCs. Results indicate that financial support from ministry and municipalities enables SACCs to survive. From the perspective of SACCs it has been observed that government uses new public management tools in a modern fashion to transfer the responsibility onto the shoulders of non-governmental SACCs, while the government reduces its contribution to symbolic financial support and the request for accountability. The current government-NGOs relationship, based on neoliberal ideology and new public managements tools, has negative consequences and does not ensure 
social services for socially excluded target groups, especially in a country with a sizable welfare gap.

\section{KEYWORDS}

Non-governmental organizations, social rights provision, cooperative governance deficit model, socially vulnerable children, neoliberalism

\section{NOTE}

The author grateful to the Lithuanian SACC Association and its representatives, who took part in the research and shared their experiences.

This research received no specific grant from any funding agency. The author's salary was paid by Vytautas Magnus University. 


\section{INTRODUCTION}

A typical characteristic of a welfare state is the expansion of social rights to include the most vulnerable individuals: it is a cause which has been historically supported by non-profit human service providers. In democratic countries, the welfare state was created after uniting the efforts of the non-profit and government sectors, as a result of trusting one another and cooperating. ${ }^{1}$ The role of the nonprofit sector in the creation of social welfare has been no less significant than that of the government. The tradition of new public management (hereinafter NPM) came to these countries when the welfare system had already been developed. The ideology of neoliberalism and NPM updated the relationship between the non-profit sector and the government with mechanisms based on market logic that resulted in unforeseen negative consequences. ${ }^{2}$ These consequences are: the weakening of the civic role of NGOs, their transformation into more bureaucratized, profit-seeking and resourcedependent entities, and their distancing from certain target groups. ${ }^{3}$

Kuti (1999) emphasises that the non-profit sector of Central and Eastern European countries faces not only problems that are common to the respective sector of the U.S. and Western Europe (which is considered to be the strongest in the world) but also with many other pressures arising from different political, administrative, social, and economic foundations. These countries ran into the welfare gap, while the system of cooperation between the non-profit sector and the government, as well as the country's welfare system, had to be created. In 1999, Kuti concluded that the countries of the former Soviet bloc are highly dependent on foreign support and that in the near future this will result in the NGO sustainability crisis, the solution to which will be of vital importance (p.59). ${ }^{4}$ Now, two decades after Kuti shared his insights (1999), it is particularly significant to study the conditions under which the non-profit sector is functioning, especially in the field of human services. Human services are defined as direct support of an individual which requires not just one-off help or a campaign but intense and often professional work, e.g. education, health, and social services. $^{5}$

\footnotetext{
${ }^{1}$ Nicole P. Marwell and Thad Calabrese, "A deficit model of collaborative governance: Governmentnonprofit fiscal relations in the provision of child welfare services," Journal of Public Administration Research and Theory 25.4 (2014); Taco Brandsen and Ulla Pape, "The Netherlands: The paradox of government-nonprofit partnerships," Voluntas: International Journal of Voluntary and Nonprofit Organizations 26.6 (2015).

2 Ibid.

3 Lester M. Salamon and Stefan Toepler, "Government-nonprofit cooperation: Anomaly or necessity?" Voluntas: International Journal of Voluntary and Nonprofit Organizations 26.6 (2015); Taco Brandsen and Ulla Pape, supra note 1; Helmut K. Anheier, Nonprofit organizations: Theory, management, policy (Routledge, 2014).

${ }^{4}$ Eva Kuti, "Different Eastern European countries at different crossroads," Voluntas: International Journal of Voluntary and Nonprofit Organizations 10.1 (1999): 59.

5 Taco Brandsen and Ulla Pape, supra note 1; Helmut K. Anheier, supra note 3.
} 
Lithuania, like many other Central and Eastern European countries, was imbued with the spirit of neoliberalism and adapted the principal tools created within the NPM tradition but emerged in a completely different social, economic, and cultural context. Using Western typology, the Lithuanian welfare state can be attributed to the hybrid "corporatist-Bismarckian-clientelistic" model slowly drifting towards a liberalmarginal one. ${ }^{6}$ The current extreme market orientation is not impacted by social support institutions and is combined with conservative ideologies about women and family. ${ }^{7}$

The finances for social security are also not optimistic. Lithuania has faced insufficient financing allocated for social protection, which, despite GDP growth, has gradually declined from $14.2 \%$ in 1995 to $13.4 \%$ in 2004 and $11.2 \%$ of the GDP in 2016. ${ }^{8}$

Since joining the European Union, Lithuania has established funding based on business logic, including social services for the most vulnerable groups in society. This has opened the window for NGOs to enter to social services marketing field, especially with new social services. ${ }^{9}$

With a large gap in welfare, where financial resources are very limited and the demand for services is very high ${ }^{10}$, there is a very high risk that the welfare of vulnerable groups in society and those who work with social excluded ones will be severely affected. It is therefore important to investigate the perspective of NGO professionals on the possibilities to help the most vulnerable target groups.

The case of school-age childcare centres (SACC) was chosen for the study, though it is likely that the processes that will be identified will generally also apply to NGOs that provide social services to other socially vulnerable groups as well, e.g. those involved with fighting violence against women or with the disabled. The first SACCs were created by NGOs and developing after the restoration of independence of Lithuanian Republic in 1990. At SACCs the children are not only supervised but also socialized, they are provided psychological support and assistance with school homework, they are given meals, and so forth.

\footnotetext{
6 Jolanta Aidukaite, Julija Moskvina, and Daiva Skuciene, "Lithuanian welfare system in times of recent crisis"; in: Challenges to European welfare systems (Cham: Springer, 2016); Helmut K. Anheier, supra note 3 .

7 Dalè Kabašinskaitè and Maren Bak, "Lithuania's children's policy in the period of transition," International journal of social welfare 15.3 (2006).

${ }^{8}$ Eurostat, "Total general government expenditure on social protection" (2017) // https://ec.europa.eu/eurostat/statisticsexplained/index.php?title=File:Total_general_government_expenditure_on_social_protection,_2017_(\% 25 of GDP).png.

9 Natalija Mažeikienè, Rasa Naujanienè, and Jonas Ruškus, "What is mixed in welfare mix? Welfare ideologies at stake in the Lithuanian case of social service delivery," European journal of social work 17.5 (2014).

10 Ibid.: 645.
} 
Research evidence speaks about the importance of SACCs functioning to the contemporary welfare development. Cartmel and Hayes (2016) carried out an overview of literature on school-age childcare during out-of-school hours and provided science-based evidence that good-quality supervision and education services provided to school-age children improve their emotional, cognitive and social development and have a positive effect on family life. In the developed countries, SACC is a tool which helps ensure successful development of a child, contributes to the balancing of family and work, and improves the overall welfare of all family members. Childcare and education services contribute rather significantly to the decrease of social exclusion and the implementation of single mothers' work and childcare responsibilities. ${ }^{11}$ This is particularly significant to single mothers. A study by Kröger (2009) showed that European lone mothers' "informal and formal resources did not adequately meet their childcare needs. A lone mother who does not have access to informal resources to cover the gaps in the childcare arrangement may be faced with care poverty in any country, in any care regime". ${ }^{12}$ In order to solve the issues of social exclusion, reconciliation between work and childcare, and protection of social rights, school-age childcare has become one of the most rapidly growing service sectors. ${ }^{13}$ Services of this type contribute not only to the child's welfare but also to the family's and the state's social and economic development.

The aim the paper is to study how the nongovernmental SACCs working with children from poor and social excluded families operate in the neoliberal minded government of social services.

The following research questions were raised: What are experiences of NGOs operating on the ground in the context of new public management tradition while ensuring the services for most vulnerable people? How do they experience the financial support and the role the government? What are the SACCs experiences about diversified fund raising? Do the SACCs experience sustainability or survival crises?

To fulfil the aim and answer the research questions qualitative research methodology was applied. The first part of the study is related to the methodological approach and the broader context in which SACCs operates. Then the analyses of qualitative interviews and discussion followed by conclusion are presented.

\footnotetext{
11 Jennifer Cartmel and Amy Hayes, "Before and after school: Literature review about Australian school age child care," Children Australia 41.3 (2016).

12 Teppo Kröger, "Lone mothers and the puzzles of daily life: do care regimes really matter?" International Journal of Social Welfare 19.4 (2010): 398.

13 Jennifer Cartmel and Amy Hayes, supra note 11.
} 


\section{THE CONTEXT OF SACCS' FUNCTIONING IN LITHUANIA}

The present Lithuanian social assistance system is carried out with help of the state, municipalities and NGOs. The historical and political conditions determine that social services do not cover an influential part in the social security system. Poor and uneven financing of NGOs leaves the delivered social services in uncertainty. ${ }^{14}$ That is very true for the social services dedicated to children at risk.

In Lithuania, at-risk children's social assistance services are provided in combination with psychological support and education services by SACCs, which were first established over two decades ago in order to deal with children's welfare issues, especially those faced by children raised in families with complex problems, by a single parent, or in poverty.

According to the data of the Ministry of Social Security and Labour (MSSL), in early 2018, there were 369 SACCs attended by 9,348 children in Lithuania. There were 9,786 at-risk families with 18,415 children in $2017 .{ }^{15}$ Discussions in the public sphere usually focus on these families. However, the issue extends well beyond them: 27.1 percent $(140,432)$ of children in Lithuania live with only one parent, usually the mother (23 percent). ${ }^{16} 48.4$ percent of the children in these families were suffering from poverty in 2017. In total, 21.2 percent of all children living in Lithuania were at risk of poverty after accounting for received benefits. ${ }^{17}$

There is a very pressing need for aid to children who are poor, neglected, or have suffered from violence. In 2017 just 7 percent of children living in poverty or with just one of the parents have the possibility to attend SACCs. Under current circumstances, when a third of all children in Lithuania live with just one of the parents and a quarter of them live in poverty, the need for SACC services is met only rather symbolically. A third of SACCs (123) in Lithuania have been established by municipalities, whereas the remaining 66 percent operate under nongovernmental organizations, religious communities, or other organizations and enterprises (hereinafter NGOs). ${ }^{18}$ These numbers not only confirm that there are issues with children's welfare in the country but also suggest that the welfare of at-risk children is not considered a priority and that these types of services for children are not seen in the broader context (a measure of promoting work and family life reconciliation,

\footnotetext{
14 Natalija Mažeikienè, Rasa Naujanienè, and Jonas Ruškus, supra note 9: 645.

15 State Children's Rights Protection and Adoption Service, "Activities reports" (2018) // http://www.vaikoteises.It/media/file/SPIS\%20ataskaita\%20sutvarkyta.pdf.

16 Vlada Stankūnienè, Marè Baublytè, and Aušra Maslauskaitè, "Single Mother Families in Lithuania: Demographic and Socio-Economic Characteristics," Sociology. Thought and Action 38 (1) (2017) // DOI: 10.15388/SocMintVei.2016.1.10310.

17 Statistics Lithuania, "Poverty risk level" (2018) // https://osp.stat.gov.It/statistiniu-rodikliuanalize?hash=dd312b7c-edc3-4ad3-81ce-534c500cce98\#/.

18 Ilona Tamutiené, "133000 Lithuanian children live in poverty: how to help them?" vdu./t (2019-02-13)

// https://www.vdu.lt/lt/133-000-lietuvos-vaiku-skursta-kaip-padeti/.
} 
job creation, sense of community and citizenship), while the activity's administrative system, which influences the development of NGOs, is problematic.

The state began supporting the non-profit sector by using market mechanisms such as competitive project funding based on the lowest bid, big commitments, and the demand for responsibility. Non-profit operating in the field of culture is typically focused on short-term initiatives. ${ }^{19}$ Non-profit operating in the field human services (social and health) typically focuses on long-term activities, but the support possibilities are the same as short-term initiatives.

Two-thirds of all SACCs operate under the conditions of constant stress and uncertainty about their future, while their activities are vitally dependent on the project-based competition funding by the Ministry of Social Security and Labour (hereinafter MSSL). This partial funding was the MSSL's response to the poor condition of SACCS, whose even minimal survival was not ensured by the municipalities to whom the responsibility was delegated for the identification of demand for social services as well as their planning, organization, funding, supervision, and control. ${ }^{20}$ MSSL started providing partial funding for SACCs projects from Child Welfare programme in 2007. ${ }^{21}$

In 2017, 3.6 million euros were allocated for the funding of 285 SACCs (for continuous activity in 249 SACCs and for 36 newly established SACCs). The maximum amount allocated for a single SACC project was 14,500 euros in 2017; in 2019, it was raised to 16,000 euros. ${ }^{22}$ Regardless of the number of children attending the SACC or the status of the SACC'S founder, competition-based funding can be allocated both to municipality-funded and to nongovernmental SACC projects. On average, monthly support for a SACC working with 25 children amounts to about 1,200 euros for all expenses (salaries, children's feeding etc.). For a nongovernmental SACC to take part in competitions organized by the MSSL for the funding of the centre's activities, no less than 10 percent of the project budget has to be co-financed by the municipality.

\footnotetext{
19 Marina Mikhaylova, "Project Governance beyond Foreign Aid: Mediating Neoliberalism in Lithuania," PoLAR: Political and Legal Anthropology Review 41.2 (2018).

${ }^{20}$ Law on Local Self-Government of the Republic of Lithuania, Official Gazette, 1994, no. 55-1049; Law on Social Services of the Republic of Lithuania, Official Gazette, 2006, no. 17-589.

21 Third sector, "Child day care centres must to look for additional financial sources" (2013) // http://www.3sektorius.It/pilietines-iniciatyvos/naujienos/2013-02-01-vaiku-dienos-centrai-turi-ieskotipapildomu-finansavimo-saltiniu/.

22 Ministry of Social Security and Labour, "Non-governmental organizations sector. Children's Day Centres Call" (2018) // https://socmin.Irv.It/It/veiklos-sritys/nevyriausybiniu-organizaciju-sektorius/vaiku-dienoscentru-konkursas.
} 


\section{METHODOLOGICAL APPROACH}

The dependency theory states that the government and the NGOs are partners rather than competitors. Recognition of such a partnership is manifested in the direction of public finances towards NGOs. This is precisely how the government enables NGOs to conduct their activities while pursuing its own goals - to carry out its primary responsibility for the public good, which in the context of this article is the social rights of vulnerable children.

State support can take various forms, such as an official allocation of money (a grant), contractual funding, which is usually related to public procurement or competitive project funding, provision of premises, consultations, tax cuts, etc. Some of the small NGOs are highly dependent on state support, as it is vital to their financial stability. ${ }^{23}$ State support is highly important to NGOs that provide professional services to people; moreover, to the NGOs that provide services to socially excluded groups, it is the principal source of funding.

It is claimed that diversification of financial sources is more favourable than dependence on one financial source. When an NGO receives finances from different funds, it produces more effective results. ${ }^{24}$ For the purpose of ensuring organizational activities during these difficult times of neoliberalism, diversification of funds would indeed seem to be a safer and more attractive alternative, especially in the management of financial and economic risk. ${ }^{25}$ This study looks at the fund diversification experiences of the SACCS, but the main diversified sources in our case is the different public programmes.

According to the literature on non-profit sector research, organizations aim to attract public finances by adapting to the requirements and standards and by competition. The government's influence gradually distances them from their principal mission and results in bureaucratization, over-professionalization, and politicisation. ${ }^{26}$ It has been observed that the non-profit sector is becoming increasingly reminiscent of the business sector. This similarity is characterized by competition for funding and activities related to the drawing of funds from various sources, including different public programs and public procurement. These processes result from the state-level factors, such as saving at the expense of social costs, the emphasis on accountability in contractual relations, and the transfer of

\footnotetext{
23 Helmut K. Anheier, supra note 3.

24 Jessica L. Berrett and Bradley S. Holliday, "The Effect of Revenue Diversification on Output Creation in Nonprofit Organizations: A Resource Dependence Perspective," Voluntas: International Journal of Voluntary and Nonprofit Organizations 29.6 (2018).

25 Heli Wang, Jay B. Barney, and Jeffrey J. Reuer, "Stimulating firm-specific investment through risk management," Long Range Planning 36.1 (2003).

26 Helmut K. Anheier, supra note 3, 289.
} 
responsibility for social services to the local self-government. ${ }^{27}$ These processes occurring in the field(s) of social policy and administration is relevant to Lithuanian study case because they serve as the setting in which the experiences of research participants occur.

Based on qualitative interviews with SACCs data the author found that the survival of SACCs are marked not with only lack of finances, but with great responsibility for the welfare of social excluded ones. The author of the SACC's study argues that local self-government transfer of responsibility but not public finances for social services to the NGOs. In order to explain such mechanism the cooperative governance deficit model is used. ${ }^{28}$ Marwell and Calabrese (2014) studied the mechanisms of the provision of children's welfare services. The starting point of their analysis was children's social rights as a public good which the government must provide using tax-payer money. The same departure point was taken by the author of this article and was highly expressed by the research participants as well.

Marwell and Calabrese (2014) conceptualized the cooperative governance deficit model, which demonstrates how the government delegates the safeguarding of children's rights to the non-profit sector but does not allocate enough funds to ensure the protection of these rights. This highly relevant for the Lithuanian case analyses because Lithuania has a welfare gap and is one of the poorest EU countries.

Combining this deficit model theory with finance management practices, the article argues that those practices make it challenging for the organizations to survive and ensure high quality of services. Marwell and Calabrese (2014) argue that the state's ability to protect the social rights of vulnerable children relies on the provision of social services by the non-governmental sector. Their reasoning reveals how the shortage of funding for the essential and vital services to children is covered by the NGOs themselves, while the government sector uses contracts to transfer its responsibility for the protection of children's welfare on to the shoulders of the NGOs and uses the funds it has saved in other areas. ${ }^{29}$ The main tools of NPM such as competition for the public funds followed by contracts (if the project wins) are seen as tools helping to transfer the responsibility for social welfare of vulnerable children onto the shoulders of NGOs. Finance management practices and the severity of deficit occur in a different context, which will be presented by employing context analyses.

\footnotetext{
27 Ibid., 291.

28 Nicole P. Marwell and Thad Calabrese, supra note 1.

29 Ibid.
} 


\section{Research method}

The data was analysed using the method of content ${ }^{30}$ and context analysis. ${ }^{31}$

The qualitative structured interview method is used to collect data from the ground. During January and February 2018, 62 qualitative structured interviews with experts working in non-governmental SACCs were conducted. SACCs development processes are examined from the viewpoint of those who provide the services to children.

Research participants were contacted through the Association of SACCs, which sent a file with integrated research aim, ethical principles, and researcher contact information, and open-ended questions of the study to each member of the Association.

The research tool included demographic questions as well as inquiries about the challenges of survival, compatibility and sustainability between support, administrative burden, and provision of services. The study participants sent the data to the researcher (author of the paper), with whom they communicated whenever any answers required clarification or elaboration.

In compliance with ethical principles, the paper does not reveal the first or last names of participants or the names of SACCs in which they are working. Original quotations of the research participants are used to support arguments. Research findings were validated in the seminar with the SACCs Association and MSSL members.

A directed approach to content analysis was applied. ${ }^{32}$ Where the principal subjects of content analysis matched the groups of structured open-ended questions, such as the role of the MSSL's support of SACC development, the municipality's perspective and the impact of its support of SACC development, the significance of administrative burden to the implementation of the SACCs' main mission.

Context analysis made it possible to take a broader look at the processes of cooperation between the government and the non-profit sector and contributed to the understanding of the problem as well as its contextualization in Lithuania. The SACCs and government operate under the influence of historical experience, neoliberal ideology, broader social and economic, and cultural factors. The development of the human services providing and development relays on the broader context than only collaboration between government and NGO. The broader context

\footnotetext{
30 Hsiu-Fang Hsieh and Sarah E. Shannon, "Three approaches to qualitative content analysis," Qualitative health research 15.9 (2005).

31 Rikke Sand Andersen and Mette Bech Risør, "The importance of contextualization. Anthropological reflections on descriptive analysis, its limitations and implications," Anthropology \& medicine 21.3 (2014). 32 Hsiu-Fang Hsieh and Sarah E. Shannon, supra note 30.
} 
analyses is relevant to better understanding of the qualitative data obtained by the qualitative structured interview method.

\section{RESEARCH PARTICIPANTS}

Out of the 62 research participants, only 3 were male, the remaining ones were female (Table 1 ). The average age of the study participants is 47 . The research participants' professional experience at SACCs was 8 years, and 68 percent of them have been working at the SACC since its establishment. Only 21 percent work fulltime, and only 4 of these have long-term contract. The remaining ones are employed part-time, on a short term contract. The status of the job contract is determined by the amount of funding won in competitions. Typically, the short-term contract is terminated in the end of December. The future of job contracts whether competitionbased funding has been received and what amount has been allocated. Usually this bureaucratic, administrative period takes 3 months, i.e. the contracts are terminated for this duration with no less than 79 percent of the study participants. During this time period, they work on voluntary basis. Permanent job contracts are signed only with 21 percent of the research participants. The research participants worked in SACCs that have been operating for the average duration of 10 years.

Table 1. Sociodemographic characteristics of research participants

\begin{tabular}{|c|c|}
\hline \multicolumn{2}{|c|}{ Sociodemographic characteristics } \\
\hline Number of research participants, $\mathrm{N}$ & 62 \\
\hline Age of research participants, years, M (min-max) & $47(23-65)$ \\
\hline Professional experience at SACCs, years, M (min-max) & $8(1-20)$ \\
\hline \multicolumn{2}{|l|}{ Sex } \\
\hline Males, \% (N) & $5 \%(3)$ \\
\hline Females, \% (N) & $95 \%(59)$ \\
\hline \multicolumn{2}{|l|}{ Employment } \\
\hline Total, \% (N) & $100 \%(62)$ \\
\hline Full time, \%(N) & $21 \%(13)$ \\
\hline Part time, \% (N) & $79 \%(49)$ \\
\hline Working time suspended until next project, \% (N) & $61 \%(38)$ \\
\hline \multicolumn{2}{|l|}{ SACC } \\
\hline Years of activity since establishment, M (min-max) & $10(1-21)$ \\
\hline Number of children in $2017, \mathrm{M}$ (min-max) & $28(15-50)$ \\
\hline
\end{tabular}




\section{CHALLENGES OF SACCS: "IT'S A GREAT SHAME THAT NGOS CONTINUE TO PLAY THE ROLE OF A PLEADER RATHER THAN A PARTNER"}

SACCs that provide childcare services operate within the structures of various larger NGOs and religious organizations and, in very rare cases, as separate legal entities. It must be noted that SACCs are a part of NGOs' functions, but the program itself is a small self-sufficient part of NGOs whose leaders are responsible for financial income and expenditure. The experience of the research participants is characterized by a representative quote: "Write the projects and you will receive the funding". Therefore, it is no coincidence that the study participants clearly communicated the experiences that all SACC-related issues faced by those who initiated SACCs in Lithuania are deemed to be their personal matter rather than a collective responsibility. "If the state needs SACC activities, then why do their activities depend on a person being proactive, as otherwise the SACC would not function" (SACC 44).

In order to ensure at least minimal activity, non-governmental SACCs apply for competitions of the ministry or the municipalities and seek sponsors.

Looking at the role of the MSSL in the development of SACC activities, it could be argued that it plays a vital role in the establishment of new SACCs as well as the support of already existing centres' activities. The research participants were generally positive towards the role of the MSSL in their survival; however, in addition to this, they also specified a big bureaucratic burden, uncertainty regarding competition-based funding, and the challenge of surviving when the funding of the year's first quarter is late as a result of bureaucratic mechanisms. Notably, the responsibility for the organisation of social services in the area falls on the municipalities. For this reason, the research participants who have represented the SACC's interests at the MSSL are united by the experience related to the requirement of influencing the municipal councils and administrations so that they would start implementing the responsibilities that have been assigned to them by law.

\section{Municipal support}

The issue of municipal support is related not only to a lack of finances but also to the attitude towards the problems of NGOs and children's welfare. Table 2 presents the typical structured answers of the SACCs that participated in the study: from the non-allocation of support by municipalities to a few exceptional cases when a larger amount was allocated. Nine of the researched non-governmental SACCs indicated that they did not receive any funding from the municipality in 2017. The municipalities that did not support the SACCs financially at all ignore the problem of child poverty, social exclusion, and their duty to assume the responsibility and work 
on removing social exclusion effectively, i.e. to improve children's social welfare and protect their social rights. Children poverty has impacted all regions of Lithuania, with no exceptions. For this reason, the municipalities that have not established SACCs and do not support the non-governmental SACCs can be seen as neglecting their own responsibilities and the needs of this population segment.

Based on the collected research data, most municipalities provide only symbolic support to SACCs, i.e. very irregularly and in small amounts (see Table 2). Nevertheless, this support is significant to SACCs as formally it can be treated as a contribution from the municipality and thus constitutes the 10 percent contribution required by the MSSL. It seems that this formal 10 percent requirement is an accurate representation of how much the municipalities "care" about SACCs.

Table 2. The contribution of municipalities into the support of non-governmental SACCs* Did not provide support $(\mathrm{N}=9)$

"It is a great shame, but we have not received any help from the municipality $<. . .>$ I think that childcare centres are put in the position of orphans: the municipality publishes an article that a new childcare centre has been opened in their area, puts a large "check mark" for itself, and it all ends there. We have opened a second childcare centre, but the situation is the same".(SACC62)

"There is no municipality-founded SACC in our city. There is the only one, which we founded with the support from the Ministry of Social Security and Labour. So, the policy is quite clear. If our centre was not on the same premises as the Youth Centre, we would have to shut down and children would be left on the street" (SACC17).

Symbolic $(\mathrm{N}=18)$

"The Social Support Division allocated some food vouchers several times in January, when the funding from the ministry was stopped. The municipality's attitude is that we have to continue writing projects and receive the funding then, while they have no funds for the centres" (SACC35).

"Over the last 4 years, we have received: 2000 euros for a fence on the SACC's premises and 570 euros for partial rent of buses for a trip to Klaipedda" (SACC22)

"Transportation of children to Vilnius was provided once". (SACC50)

Access to the premises and contribution to payment for utilities only $(\mathrm{N}=16)$

"The municipality's most frequent support was the provision of premises in the form of a lease, or small amounts of money for utilities provided through competitions (or sometimes in other ways)" (SACC2).

"The municipality provides full support for the premises. Unfortunately, there is no other support" (SACC33).

"In accordance with the Support for Non-Governmental Organisations and "the Social Support and Healthcare Program", the municipality's administration allocated 1,000 euros to cover utilities and other expenses (but not salaries)" (SACC13)

Larger support: contracting for the services $(\mathrm{N}=5)$ or provision of premises with additional financial support $(n=14)$

"We have signed a contract with the district municipality for the provision of the social services to 15 children and their parents. We won public procurement competition for that kind of financial source. We present the invoices to the municipality every month and receive payment. Our centre is attended not just by children from at-risk social groups (also from large families, disadvantaged families, orphans, or if the parents have emigrated, or the children from one-parent families). In total, there are 40 children" (SACC21).

"In 2017, the municipality announced project competitions for the funding of the services of childcare centres and a children's summer camp. 5,000 euros were allocated for the job salaries, for measures, activities, and utility taxes. 1,200 euros were provided for a children's summer camp" (SACC11)

*Original responses of the informants that correspond to the common type of support by category 
A more significant type of support of the non-governmental SACCs is provided in the form of a lease and the coverage of utility taxes (see table 2). Even though this form of support is very important to SACCs, in conjunction with the support provided by the MSSL it is only sufficient to enable survival.

Instances of more sizable support could include exceptional cases when municipalities finance SACCs after they win competitive public procurement or project funding. In such cases, in accordance with the contract between the SACC and the municipality, the services are paid for out of the municipality's budget. As an exception, several municipalities can indicated that announced competitions for the funding of the services by childcare centres and summer camps (see table 2). Even though the amounts of funding are just enough to hover on the edge of the poverty line, after taking into account the experiences of other research participants, when the municipalities contribute less or do not contribute at all, such support is to be considered more sizable, especially in cases when the MSSL's competitions are won as well.

The research participants' experiences have revealed that none of the programs dedicated to the financing of SACCs provide funding which would ensure high-quality and stable provision of services. The support allocated by the MSSL does enable the existential survival of the SACC, but it is not sufficient. Such a position may be understandable in the legal context, in which the responsibility for the development of social services falls not on the central but on the local government. However, the local government has not assumed the full responsibility for this and, in many cases, transferred it on to the shoulders of non-governmental SACCs, while only contributing minimal (symbolic) amounts itself, or none. From a quantitative perspective, it would seem that SACCs are funded, they participate in project competitions and win them. However, after taking a closer look at their daily activities, it becomes clear that this dispersed, unbalanced, and fragmented funding raises challenges of day-to-day survival and bureaucratic burdens. The situation of the MSSL and the municipal support can be summarized with the following quote: "The desire and the effort to do as much as possible at the expense of others while spending as little money as possible" (SACC12).

\section{THE CHALlenges OF THE SUSTAINABILITY OF ACTIVITIES AND} BUREAUCRATIC BURDENS: SUCCESSFUL FAILURES

According to the study participants, "the support received by the SACC through projects is not enough to provide good-quality services while preserving professional employees. The job salary we can allocate is pathetic" (SACC13). In spite of these 
poor conditions, keeping it from becoming even worse is problematic. While the competition-based funding by the MSSL remains fundamental to ensuring the SACCs' activities, the administrative-bureaucratic mechanisms cause challenges related to the sustainability of activities and bureaucratic burdens. Research participants unambiguously recognized the support by the MSSL as important and, simultaneously, as raising the problem of the sustainability of activities for the first quarter of every year. This is the approximate amount of time taken up by bureaucratic processes before the funds reach the SACC which has won the projectbased funding. During the first months of a year, maintaining the employees and continuing the activities becomes a very difficult challenge:

At the start of every year, we work while taking risks, crying to the sponsors, and begging. Even now, it is February already, yet we have not only received no money but also have no idea whether the contract will be extended for this year. The employees are working, the children are eating, we are using the electricity, and all the while we are uncertain if we will be able to pay for it. However, we can't tell the children that we will only work when we are allowed. The entire point of the SACC would then be negated - if we need the children only when money is available... We are completely dependent on the ministry, but we can trust only in our sponsors: this is the sad part of our life (SACC14).

As may be observed in the interview excerpt above, SACCs have to expend a lot of effort in pursuit of support when the minimal funding provided by the MSSL is stopped. The experiences of the study participants revealed that the situation is uneven: some SACCs operate on voluntary basis, i.e. without salaries; others find the opportunity and, for those few months the salaries are paid by the municipality; while yet others do not terminate their activities because they are supported by the parish or an organization which is above it in the structure (Save the children, Caritas, etc.). In exceptional cases, the research participants suspend their activities, but typically they refrain from suspending or terminating it because of moral obligation to the children:

We did not suspend [activities] during any of the years, we worked on a voluntary basis because the centre is the centre is the most needed by the children during the winter. Maintaining the staff, providing children with services while working for a very minimal salary, and doing [unpaid] voluntary work - you can't tell the children that the centre has no money and it will not operate for a few months (SACC11).

This moral obligation satisfies the needs of the children who attend the SACC but not of the employees. Their paid work time is temporarily suspended, because they receive no income for the work that they do: 
At the end of project funding, the employee is dismissed. The organization has no financial possibilities to pay the worker with its funds: it has to pay the utility taxes and to provide children with food, because when the funding ends on 1 January, the SACC'S activities become the business of the organization itself (SACC1).

SACCs overcome the challenges, because they survive and maintain sustainability of activities. However, over the several decades of SACC operations, a balanced policy for their funding has not been established at either the national or local level. It would be appropriate to describe this situation with the concept of the success of failure defined by Seibel (1996). ${ }^{33}$ On one hand, SACCs experience success, because they win the project-based funding; on the other hand, such a success does not enable high-quality, uninterrupted operation, whereas they have to account for the allocated funding and take on the commitments laid down in the contracts. In order to ensure that the commitments are met, additional financial sources must be found and subsequently used as payment for the support. This diversification of financial sources increases bureaucratism, which is related to the understanding of the project-based funding of each program and the preparation of the application while ensuring its consistency with the goals of the respective program and the obligation to report not only to the clients but also to the funding institution. The research participants stated that they are faced with great bureaucratic burden and an excessive responsibility.

The requirements for the childcare centres are very demanding: we assume enormous responsibility for the support to the families, we present large written reports with numbers, and the children need direct attention and contact, when can we record everything into their files??? You have to dedicate a lot of time for the management of documents, but when can you work with the children? The requirement to include as many children as possible should respectively increase the number of people working with children, whereas the funding is only decreasing. Consequently, we would have to decrease the number of children as well (SACC15).

Since the funding is based mostly on quantitative measures, i.e. oriented towards SACCs that provide services to a greater number of children, the research participants themselves admit that this flawed tradition eliminates the possibilities of working efficiently: "When one person works with 27 families, the services cannot be high-quality" (SACC5).

33 Wolfgang Seibel, "Successful failure: An alternative view on organizational coping," American Behavioral Scientist 39.8 (1996). 
The research participants indicated that it is harder to attract funds for the employees' salaries than for the children's feeding. In order to prepare competitive applications for a funding contest, to present reports, or to coordinate other bureaucratic processes, some competence is required. For this reason, the burden is placed on the shoulders of the SACC's director. However, in the situations when there is a shortage of funds available for the salaries, the SACC's head himself is often the provider of direct services to the child. In such cases, he is obligated to the bureaucratic mechanism, i.e. to presenting projects and reports in accordance with regulations, maintaining the accounting records etc., and to the children, i.e. the main mission of the SACC, which was the principal impetus to the activities in the first place. After winning the funding from several sources, a major challenge arises as to how to reconcile the responsibilities of the bureaucratic burden and the services for the children. Beating this challenge demands a lot of dedication from the employees:

The reports obligate [us] to present the required information on time, at the end of each month or quarter, without fail. This information must not be presented by just anyone, typically it is provided by the head of the project, who submits the application. It is very difficult to delegate the submission of reports or applications to some employee or volunteer, since there is no pay, and no one wants to take on this job. Report templates are changed constantly, so the reports can be quickly, efficiently and punctually prepared only by a skilled employee. Thus, for this job position, vacation and sick leave is possible only in difficult cases (SACC44).

The research participants see the bureaucratic burden that falls on them as too great, and complicating the fulfilment of their main mission:

The bureaucratic burden is too great for us and this is very sad. We are not used to it and we have to delve very deeply into it, to waste time on writing reports, while instead we could talk to the children and do our direct job. The paperwork shows that we are not trusted, as though the documents reflect actual support and help us feel improved as childcare specialists. But this is not the case (SACC34).

This burden is only increasing. I agree that everything has to be transparent, but it shouldn't sink non-profit organisations. Otherwise, it all becomes just commerce. Some space has to remain for projects that defend human values (SACC1).

The context of bureaucratic burden is related not only to technical requirements. These requirements have been created by people and they operate in the wider social context because the research participants associate strict 
requirements with mistrust in the nongovernmental sector, with ignorance of the demand for this type of services or the complexity of meeting this demand, and with dependence on the will and mercy of the politicians. A SACC which has been operating under a religious community for over 21 years reflected on the challenges it faces every year:

It seems as though SACC projects have to prove every time that the children need them and that this activity is not for the profit of the organization. After getting the funds we often have to rack our brains because they are often insufficient and the project's quality suffers from it. There is a pressing issue of staff stability - it is difficult to find specialists who would work under such conditions: for a small pay and with the knowledge that uncertainty will return on January $1^{\text {st }}$. We see the children's problems and needs, but when we talk to the authorities, we feel responsible for everything ourselves: only demands are made, while actual help is not received. More and more often there is disappointment about the situation changing, and thus the employees who worked on the project decide to change their field of work (this field is in the invisible zone for the government and "impenetrable"). Because the funding is limited, the work is only voluntary; SACC activities lack specialists who could help the children with their problems and would help them grow up and become full-fledged citizens (SACC7).

SACC7, which faces the aforementioned challenges, operates in one of the large cities of Lithuania where none of its non-governmental SACCs received any funding from the municipality in 2017 as a result of the politicians' ruling. Since the study was conducted in early 2018, the SACCs of this city were not yet certain if they could expect the municipality's support for 2018 either, because, early in the year, SACC support was a subject of political discussions. The political debates produced the following result: when public contracts were announced, it was emphasized that the municipality will purchase services for no more than 73,440 euros from 18 SACCs that will work with no fewer than 20 children and their parents. This constitutes about 320 euros for all monthly expenses per SACC or 17 euros a month per child. ${ }^{34}$ This symbolic support was offered in exchange for a serious commitment to ensuring the children's and their families' welfare. There are 21 SACCs operating within the territory of this municipality, only two of which have been established by the municipality itself. Because of this, the experiences of non-governmental SACCs reveal the situation when the municipality simply transfers the responsibility for the welfare of the SACC-attending children on to the shoulders of the NGOs. In this context, we can observe a modern mechanism created with the NPM tools which is

34 Municipality of Kaunas City, "The Report of the Public Procurement for Employment and information services for children and their families to purchase services" (2018) //

https://cvpp.eviesiejipirkimai.It/ReportsOrProtocol/Details/2018-

612496? form TypeId = 1\&fbclid=IwAR01BXUJXj9rGd9DotONi-UkHLBjxfVTNtST-xjS-PIvjrFHBUg6mEtZ1Mc. 
dedicated to the transfer of responsibility for the children's social welfare on to the NGOs' shoulders. Taking into account the contributions of the SACC employees, when they have to actually work full-time but are paid within the limits of the accumulated funds, i.e. a minimal wage (in many cases, just a symbolic pay, as only part-time hires can be afforded), we may conclude that, thanks to its unpaid labour, the SACC subsidizes the municipality.

The SACC operates under the conditions of poor funding, strict requirements, and uncertainty about the future: "The future of our SACC is also unclear. The community of the sisters is not capable of implementing this project on its own, which it has been conducting for 21 years. We are thinking of changing our activities in the future. This year could be the fateful one, because we do not have the manpower to sustain the current situation" (SACC3). The fact that they still continue their activities could be interpreted as a moral obligation. The research participants expressed this moral obligation with a rhetorical question: "If not us, then who will provide services to the excluded children in our community?". This typical rhetorical question arose from the recognition of reality. The municipalities that do not have either municipality-founded or NGO-founded SACCs clearly attest to the possibility and actuality of a negative answer to the study participants' rhetorical question. Sensitive and usually pro-social persons who deal with children's problems and suffering become associated with the children through a social connection. This connection is the basis for the sustainability of SACCs. However, we can assume that this moral obligation to children provides favourable conditions for the transfer of municipal responsibility onto the shoulders of NGOs while demonstrating quantitatively that the municipality is doing something and taking some care of socially excluded children. This modern transfer of responsibility on to the shoulders of altruistically-minded SACC employees should be examined more thoroughly.

\section{DISCUSSION AND CONCLUSION}

This article examines how NGOs working with children from poor and social excluded families operate in a neoliberal environment.

In order to understand and explain how SACCs operate on the ground, the cooperative governance deficit model was employed. ${ }^{35}$ Despite that the cooperative governance deficit model was developed in the different cultural, economic, social context and based on a different research method, it was the most appropriate analytical tool to analyse and explain the experiences of the SACCs operating on the ground.

35 Nicole P. Marwell and Thad Calabrese, supra note 1. 
The study revealed questions about who must pay for social services for children from poor and socially excluded families still open in Lithuania. Despite that legally it is government's responsibility, the data brought from the practical level shows the ways of transferring this responsibility on the shoulders of NGO. The research results support the claims by Hasenfeld, Garrow (2012) that, with the rise of neoliberalism, social rights are at risk. ${ }^{36}$

The study revealed that the principles of solidarity and partnership between the government and the nongovernmental organisations were underutilized in the pursuit of children's welfare. This contributes to the wide gap between political goals and their practical implementation. According to the Commissioner for Human Rights of the Council of Europe, "While Lithuania has a relatively well-developed institutional and policy framework for the protection of children's rights, there is a considerable gap between the stated policies and their implementation. The Commissioner urges the authorities to address this matter, and to ensure that all children are in a position to effectively enjoy all human rights. It is especially important to improve coordination between national and municipal authorities in charge of protection of children's rights, to ensure sufficient staff and expertise to provide child-focused social services in all municipalities". ${ }^{37}$

Based on the data of the SACC study, municipalities use the NPM tools in a modern fashion to transfer the responsibility on to the shoulders of nongovernmental SACCs, while limiting their own contribution to symbolic support, great administrative burden, and the demand for accountability. The collected research data directly confirms the statement by Marwell and Calabrese (2014) that "collaborative governance arrangements [by the government and nongovernmental organisations] to secure public goods threaten government's ability to discharge its responsibility to citizens". ${ }^{38}$

The research data also uncovers the processes of how the individuals that had taken on the SACC initiative and responsibility also become hostages of the neoliberal-marginal welfare system. While they intended to help the poor and abandoned children, instead of the government's support and encouragement to act they encountered restrictions, enormous competitions, administrative burden and other processes that transform the public issue into their own private matter. Such a situation is related to insights by Connell, Fawcett, Meagher (2009), who point out that "each part of an organization functions like a profit-making firm, with its

\footnotetext{
36 Yeheskel Hasenfeld and Eve E. Garrow, "Nonprofit human-service organizations, social rights, and advocacy in a neoliberal welfare state," Social Service Review 86.2 (2012).

37 Nils Muižnieks, "Report by commissioner for human rights of the Council of Europe following his visit to Lithuania from 5 to 9 December 2016" (2017): 24 // https://rm.coe.int/168070a746.

38 Nicole P. Marwell and Thad Calabrese, supra note 1: 1054.
} 
managers held accountable for the income/expenditure balance. Under neoliberalism, this principle holds to the lowest level. Individual workers are treated as firms, expected to follow a profit-making logic; and they are held accountable to the organization in these terms, through 'performance management' schemes. Both organizations and individuals are required to make themselves accountable in terms of competition". ${ }^{39}$ A natural question arises: under these rather hostile conditions, how do SACCs ensure survival and sustainability?

Research results show that fund diversification ensures only survival of SACCs. It is in accordance with Wang, Barney, Reuer (2003) that the purpose of ensuring organizational activities during these difficult times of neoliberalism, diversification of funds would indeed seem to be a safer and more attractive alternative, especially in the management of financial and economic risk. ${ }^{40}$ But the study shows that fund diversification creates enormous administrative burden but not necessarily effective results as Berrett \& Holliday (2018) found. ${ }^{41}$ On the other hand, the demand for the service is 10 times greater than the supply, and thus the competition between service providers becomes meaningless, while the artificially created conditions only raise the administrative burden both for the SACCs and the governmental institutions.

However, the current situation which was marked by the enormous administrative burden to ensure the survival of the SACCs can be explained using the concept of successful failure defined by Seibel $(1994)^{42}$. This is because the funding won under competitive conditions is a success, but it does not create possibilities for high-quality services. This is related to the cooperative governance deficit model which leads to poor quality of the services provided for the socially vulnerable target groups. We assume that the SACCs and government collaboration leads to the mellow weakness scenario outlined by Adhieir (2005), when the non-profit sector is encouraged to act in the areas or problematic fields that politicians consider to be too expensive or unattractive to take care of themselves. SACCs' ability to survive allows the governmental sector to lay claims that "something is being done". Adhieir (2005) described this situation vividly by stating that "non-profits are the fig leaves for a political world unwilling to solve social problems in a serious way and remain under mild state tutelage". ${ }^{43}$

This study does not reflect the viewpoints of government representatives. Research samples do not include SACCs that are not members of the SACCs Association or have suspended or terminated their activities. The author participated

\footnotetext{
39 Raewyn Connell, Barbara Fawcett, and Gabrielle Meagher, "Neoliberalism, new public management and the human service professions: Introduction to the special issue," Journal of Sociology 45.4 (2009): 334.

40 Heli Wang, Jay B. Barney, and Jeffrey J. Reuer, supra note 25.

41 Jessica L. Berrett and Bradley S. Holliday, supra note 24.

42 Wolfgang Seibel, supra note 33.

43 Helmut K. Anheier, supra note 3, 377-378.
} 
in the creation of one of the first nongovernmental SACCs in Lithuania. This work was cancelled twenty years ago. Such attitudes and experiences related to services development for poor children may affect interpretation of the data.

Future research about the collaboration of NGOs and government in the realization of social welfare to socially vulnerable people on the ground is needed in different countries with differing cultural contexts. The social rights of individuals working in the NGOs with the most vulnerable people under government contracts should be researched more thoroughly.

\section{Conclusions}

The current government-NGO relation, based on neoliberal ideology and new public management tools, has negative consequences and does not ensure social services for socially excluded target groups especially in a country with a large welfare gap.

The cooperative governance deficit model in providing social assistance to children and their families is manifested in severe form in Lithuania. The government uses the new public management tools in a modern fashion to transfer the responsibility for the social services for socially vulnerable children on to the shoulders of non-governmental SACCs, while reducing their own contribution to the administration of modest or even symbolic public funds, and the request for accountability.

In order to survive the nongovernmental organization are forced to make the fund's diversification. The competitions for public finances from the different public funds are followed by increased accountability and enormous administrative burden. Challenges of survival such as lack of money, enormous administrative, long term stress due to short-term and deficit financing for the long-term services negatively shape the quality of services and quality of everyday life of SACCs.

Responsibility for human services should be transferred to nongovernmental SACCs in conjunction with funding that would enable the provision of services, while the principle of government domination should be replaced by solidarity for the sake of the common goal of children's welfare.

The administrative burden on the non-governmental organizations working with socially vulnerable people must be reduced, primarily by ensuring uninterrupted funding for long-term services. 


\section{BIBLIOGRAPHY}

1. Aidukaite, Jolanta, Julija Moskvina, and Daiva Skuciene. "Lithuanian welfare system in times of recent crisis": 419-441. In: Challenges to European welfare systems. Cham: Springer, 2016.

2. Andersen, Rikke Sand, and Mette Bech Risør. "The importance of contextualization. Anthropological reflections on descriptive analysis, its limitations and implications." Anthropology \& medicine 21.3 (2014): 345-356.

3. Anheier, Helmut K. Nonprofit organizations: Theory, management, policy. Routledge, 2014.

4. Berrett, Jessica L., and Bradley S. Holliday. "The Effect of Revenue Diversification on Output Creation in Nonprofit Organizations: A Resource Dependence Perspective." Voluntas: International Journal of Voluntary and Nonprofit Organizations 29.6 (2018): 1190-1201.

5. Brandsen, Taco, and Ulla Pape. "The Netherlands: The paradox of governmentnonprofit partnerships." Voluntas: International Journal of Voluntary and Nonprofit Organizations 26.6 (2015): 2267-2282.

6. Cartmel, Jennifer, and Amy Hayes. "Before and after school: Literature review about Australian school age childcare." Children Australia 41.3 (2016): 201207.

7. Connell, Raewyn, Barbara Fawcett, and Gabrielle Meagher. "Neoliberalism, new public management and the human service professions: Introduction to the special issue." Journal of Sociology 45.4 (2009): 331-338.

8. Eurostat. "Total general government expenditure on social protection" (2017) //

https://ec.europa.eu/eurostat/statisticsexplained/index.php?title=File:Total_general_government_expenditure_on_so cial_protection,_2017_(\%25_of_GDP).png.

9. Hasenfeld, Yeheskel, and Eve E. Garrow. "Nonprofit human-service organizations, social rights, and advocacy in a neoliberal welfare state." Social Service Review 86.2 (2012): 295-322.

10. Hsieh, Hsiu-Fang, and Sarah E. Shannon. "Three approaches to qualitative content analysis." Qualitative health research 15.9 (2005): 1277-1288.

11. Kabašinskaitè, Dalè, and Maren Bak. "Lithuania's children's policy in the period of transition." International journal of social welfare 15.3 (2006): 247-256.

12. Kröger, Teppo. "Lone mothers and the puzzles of daily life: do care regimes really matter?" International Journal of Social Welfare 19.4 (2010): 390-401. 
13. Kuti, Eva. "Different Eastern European countries at different crossroads." Voluntas: International Journal of Voluntary and Nonprofit Organizations 10.1 (1999): 51-60.

14. Marwell, Nicole P., and Thad Calabrese. "A deficit model of collaborative governance: Government-nonprofit fiscal relations in the provision of child welfare services." Journal of Public Administration Research and Theory 25.4 (2014): 1031-1058.

15. Mažeikienè, Natalija, Rasa Naujanienè, and Jonas Ruškus. "What is mixed in welfare mix? Welfare ideologies at stake in the Lithuanian case of social service delivery." European journal of social work 17.5 (2014): 641-655.

16. Mikhaylova, Marina. "Project Governance beyond Foreign Aid: Mediating Neoliberalism in Lithuania." PoLAR: Political and Legal Anthropology Review 41.2 (2018): 290-305.

17. Ministry of Social Security and Labour. "Non-governmental organizations sector. Children's Day Centres Call" (2018) // https://socmin.Irv.It/It/veiklos-sritys/nevyriausybiniu-organizacijusektorius/vaiku-dienos-centru-konkursas.

18. Muižnieks, Nils. "Report by commissioner for human rights of the Council of Europe following his visit to Lithuania from 5 to 9 December 2016" (2017) // https://rm.coe.int/168070a746.

19. Municipality of Kaunas City. "The Report of the Public Procurement for Employment and information services for children and their families to purchase services" (2018) //

https://cvpp.eviesiejipirkimai.It/ReportsOrProtocol/Details/2018-

612496?formTypeId =1\&fbclid=IwAR01BXUJXj9rGd9Dot0Ni-UkHLBjXfVTNtSTxjS-PIvjrFHBUg6mEtZ1Mc.

20. Salamon, Lester M., and Stefan Toepler. "Government-nonprofit cooperation: Anomaly or necessity?" Voluntas: International Journal of Voluntary and Nonprofit Organizations 26.6 (2015): 2155-2177.

21. Seibel, Wolfgang. "Successful failure: An alternative view on organizational coping." American Behavioral Scientist 39.8 (1996): 1011-1024.

22. Stankūnienè, Vlada, Marè Baublytè, and Aušra Maslauskaitè. "Single Mother Families in Lithuania: Demographic and Socio-Economic Characteristics." Sociology. Thought and Action 38 (1) (2017): 64-85 //

DOI: $10.15388 /$ SocMintVei.2016.1.10310.

23. State Children's Rights Protection and Adoption Service. "Activities reports" (2018) //

http://www.vaikoteises.It/media/file/SPIS\%20ataskaita\%20sutvarkyta.pdf. 
24. Statistics Lithuania. "Poverty risk level" (2018) // https://osp.stat.gov.It/statistiniu-rodikliu-analize?hash=dd312b7c-edc3-4ad381ce-534c500cce98\#/.

25. Tamutienè, Ilona. "133 000 Lithuanian children live in poverty: how to help them?" vdu./t (2019-02-13) // https://www.vdu.It/It/133-000-lietuvos-vaiku-skursta-kaip-padeti/.

26. Third sector. "Child day care centres must to look for additional financial sources" (2013) //

http://www.3sektorius.It/pilietines-iniciatyvos/naujienos/2013-02-01-vaikudienos-centrai-turi-ieskoti-papildomu-finansavimo-saltiniu/.

27. Wang, Heli, Jay B. Barney, and Jeffrey J. Reuer. "Stimulating firm-specific investment through risk management." Long Range Planning 36.1 (2003): 4959.

\section{LEGAL REFERENCES}

1. Law on Local Self-Government of the Republic of Lithuania. Official Gazette, 1994, no. 55-1049.

2. Law on Social Services of the Republic of Lithuania. Official Gazette, 2006, no. 17-589. 